\title{
Research on the Reform of Curriculum System of Electrical Engineering and Automation Specialty
}

\author{
Jingfeng $\mathrm{He}$ \\ School of Science, Xijing University \\ Xi'an, Shanxi, China \\ 573825625@qq.com
}

\begin{abstract}
According to the characteristics of applied technical talents training in China's higher education at present, this paper analyzes the present situation of the curriculum system of electrical engineering and automation specialty in colleges and universities in our country. Then it discusses in detail the basic principles of the curriculum design of electrical engineering and automation in higher education, and puts forward the construction path of electrical engineering and automation professional course system for the characteristics and development factors of electrical engineering and automation professional courses. Finally a dynamic, scientific and complete professional curriculum system is gradually formed.
\end{abstract}

Keywords-Electrical Engineering and Automation; Professional course; Curriculum system; Teaching Reform

\section{INTRODUCTION}

In the new professional catalogue promulgated by the Ministry of Education in 1998, the original strong electricity major was merged into electrical engineering and automation. The reorganized electrical engineering and its automation majors cover a wide range of disciplines, including the original power system and its automation, electrical appliances and its control, high voltage and insulation technology, and electrical technology. On the other hand, it emphasizes the penetration and integration of related disciplines, that is, weak electricity control strong electricity. The new teaching plan that is compatible with the new major has the characteristics of strengthening the basic course of the subject, adding new professional courses, and offering multi-directional elective courses.

With the development of economic globalization and the continuous progress of science and technology, mankind has entered the information age. In the process of rapid social development, the development of electronic industry has become the basis of its development. Social development is in great demand for talent. However, in many colleges and universities there are electrical engineering and automation majors associated with them. However, in many cases, the curriculum of the major is rather chaotic, lacking of practical nature, and the practice in the overall professional discipline is insufficient. Unable to form a complete, scientific, dynamic curriculum system, students enter into work slowly or show a phenomenon of lack of professional ability. In view of the characteristics of electrical engineering and its automation specialty in colleges and universities in our country at present, the main goal is to serve the actual needs and employment of the society, to cultivate more comprehensive talents who are suitable for social and economic development, are conducive to industry service, management and merger, have ideals, goals, strong knowledge base and practical ability. This is only the requirement of the development of higher education in our country, but also the important requirement of the future development trend of our country.

The major of electrical engineering and its automation based on information technology and network technology has developed rapidly in a few years. The requirements of the new electrical engineering and automation majors are obviously different from those of the traditional strong or weak electricity majors. Therefore, the education system of electrical engineering and its automation must be reformed and adjusted for the development at any time. After extensive and in-depth investigation and exploration of related enterprises, we established a new curriculum system with quality education and practice ability education as the target according to the research on the talent cultivation goal and education model of electrical engineering and automation specialty.

\section{THE SIGNIFICANCE OF CURRICULUM SYSTEM REFORM}

Electrical education in colleges and universities is a basic training for students to acquire the qualities and skills of electrical engineers. They can be engaged in design and manufacture, scientific and technological development and applied research in the field of electrical engineering. Senior technical personnel in operation, management, sales and so on. With the establishment of market economic system, the progress of science and technology and the adjustment of industrial structure, the comprehensive ability of advanced applied talents in electrical industry is becoming more and more important ${ }^{[1]}$. The demand for complex talents is getting stronger and stronger. However, the traditional talent training mode, curriculum system, and teaching methods will find that the curriculum is single, the knowledge and professional aspects are narrow, the curriculum is difficult to form a complete system, and the teaching methods and methods are backward. In order to change this situation, adapt to the demand of electrical engineering professionals in the present society, cultivate electrical engineering talents with solid 
foundation, wide knowledge, strong creative ability and high quality, it is imperative to reform the curriculum system.

As a specialized university, curriculum construction is the most basic teaching construction. Students master professional knowledge and practical ability through a series of rigorous learning and training. The course is the most basic factor that decides the teaching quality, the course choice, the course quality, directly affects the realization of the training goal. According to the characteristics of electrical specialty, we set up a new curriculum system according to the principle of "emphasizing foundation, wide caliber, multi-direction and strong application". In the second year of university, the basic course of subject is set up, and then the teaching of the core course and elective course of specialty is carried out, so as to realize the overall goal of the course teaching. The core of education is to cultivate the students' overall quality and innovative ability.

\section{BASIC PRINCIPLES OF COURSE SYSTEM DESIGN FOR ELECTRICAL ENGINEERING AND AUTOMATION SPECIALTY}

\section{A. Comprehensiveness}

The evaluation and construction of the curriculum system of electrical engineering and its automation specialty is a relatively complicated problem. In the course construction process, diversified student personality development, diversified social development and education objective of China's higher education are reflected. Therefore, in the actual design of electrical engineering and automation major curriculum system, the updating of teaching materials, teaching methods, students' learning and examination should be fully understood and understood some diversified problems. Set up a comprehensive evaluation system suitable for the development of college students.

\section{B. Systematicness}

The course system of electrical engineering and its automation specialty is worth not only simple teaching methods and means, but also the construction thought, course standard, course content, course mode, curriculum structure of electrical engineering and its automation specialty. The methods and means of curriculum education and teaching, the plan and teaching conditions for the implementation of curriculum teaching, the management of curriculum and the feedback and evaluation of curriculum, In the course of constructing the course system of electrical engineering and its automation specialty, we must fully embody the idea of sustainable development and innovation, and attach importance to the dynamic feedback idea and so on. In addition, we should pay attention to the coordination relationship between each link, should take the electrical engineering and its automation specialty curriculum system construction as a complex, dynamic, long-term systematic education and teaching engineering to gradually realize.

\section{Practicality}

In electrical engineering and its automation in the process of the construction of the curriculum system should pay attention to relevant national laws and regulations and relevant functional departments of the macro goals, but also give full consideration to their own actual conditions, in electrical engineering and its automation professional curriculum system construction and implementation, should form a can show the coarse method and characteristic of its own characteristics ${ }^{[2]}$.

\section{COnstruction of COURSE System FOR Electrical} ENGINEERING AND AUTOMATION SPECIALTY

\section{A. Determining the curriculum system from the perspective of professional characteristics and subject development}

At present, the rapid development of electrical engineering and its automation technology, especially electrical engineering and its automation technology and computer, automatic control, electronic technology and precision measurement and many other advanced science and technology achievements permeate each other, New theories and new technologies are emerging. Therefore, the curriculum system must deal with the relationship between learning knowledge, improving ability and laying a foundation for future self-learning. From the perspective of curriculum type, the professional curriculum system includes the following aspects: figure. 1. 


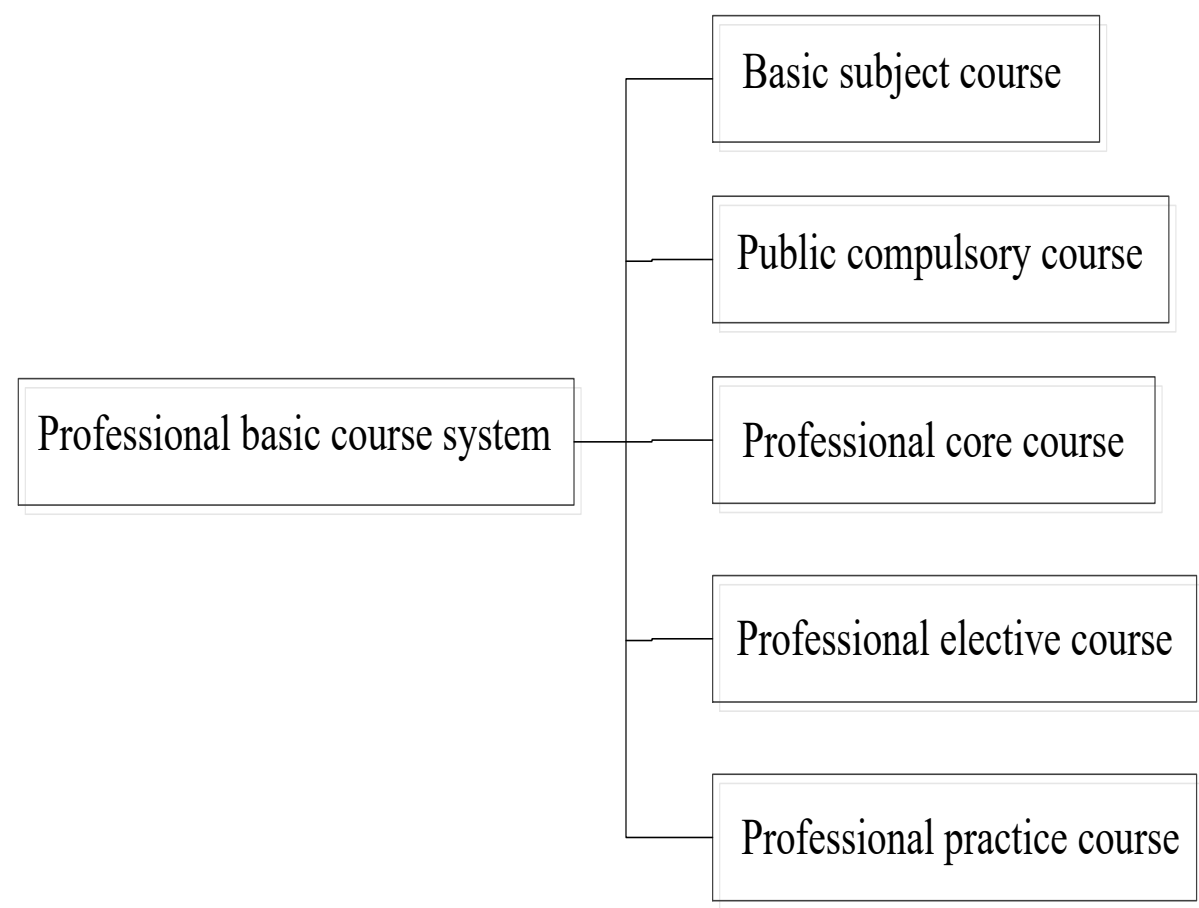

Fig. 1 Course types

To construct a new curriculum system, we must according to the electrical engineering and its automation specialty training goal orientation and applied talents knowledge structure requirement, and follow the "heavy foundation, broad caliber and direction and application of" principle, set up public required courses, subject courses, professional core courses, professional electives, and practice.

\section{1) Public compulsory course}

The public compulsory courses are not designed for a single major, but for the knowledge and foundation necessary for the relevant professional groups. They pay attention to the basic qualities of the students, the sustainable development of the students, and lay the foundation for the students to continue to study, to enable students to acquire a more generous public basic discipline, professional basic knowledge. The common basic courses consist of culture courses, tools courses and ability training courses, which are mainly to cultivate students' comprehensive ability and comprehensive quality ${ }^{[3]}$.

\section{2) Basic subject course}

The basic courses include the main courses required for electrical students, including circuit, digital electronics, analog electronics and so on. These courses focus on the basic disciplines necessary for the relevant majors in the power supply category, so that students of similar majors can easily change their major and improve their adaptability after graduation.

\section{3) Professional core course}

The professional core course are mainly to train students' basic professional skills and abilities, so that students can master the basic theory and basic knowledge of electrical engineering systematically. After graduation, students are able to engage in movement control and industrial process control related to electrical engineering. Engineering design, system analysis, system operation, research and development in the fields of electrical engineering, power electronics technology, detection and automation instrument, electronics and computer.

\section{4) Professional elective course}

The main purpose of professional elective course is to let students understand the development of the subject, the industry trends related to the profession, and the application of new technologies, to lay the foundation for exploratory learning.

\section{5) Professional practice course}

Practice is an important process for students to acquire the application ability of professional skills. The practical teaching system includes the course design of analog / digital circuit, the course design of principle and application of single chip microcomputer, the course design of electrical control and PLC, the course design of computer control technology, the practical training of electrician and electronics, the graduation design and so on. The construction of practical teaching system must conform to the law of education, take the spiral rise as the principle, and play the effect of training the students' scientific research practice ability.

\section{B. Optimizing the course structure and constructing the whole optimized course system}

In the era of knowledge explosion, we can no longer teach all knowledge to students in four years of university, but we must teach students the ability to learn knowledge in the ocean of knowledge. Therefore, the selected content must be the most basic and effective knowledge, and focus on cultivating students' scientific research practice ability and innovative 
spirit, so that students can learn living things. Therefore, from during the university is designed as follows ${ }^{[4]}$ the perspective of knowledge and ability, the course system

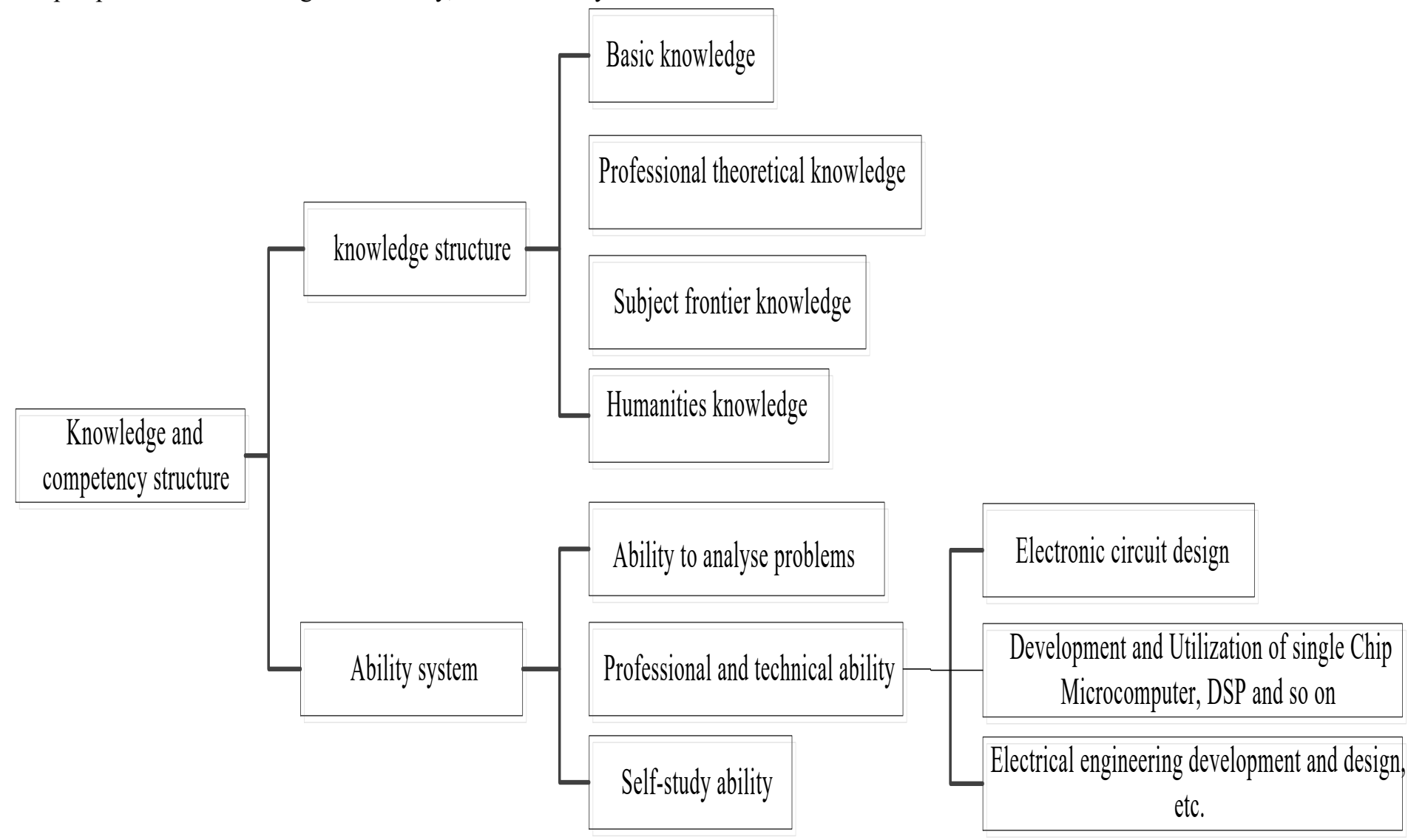

Fig. 2 Knowledge capability system

\section{CONCLUSION}

This curriculum system is based on public compulsory courses, and is based on basic courses and core professional courses. The variable and unstable subjects are set to the same course name, and the teacher decides the specific learning content according to the development of science at that time, thus forming a scientific, advanced, systematic, stable, and Extended curriculum system. On the basis of the construction of advanced electrical engineering and automation professional teaching system.

\section{REFERENCE}

[1] Zhang Ailing, Han Fuchun, Pu Qinghua. Research on the training Program and Curriculum system Reform of Electrical Engineering and its Automation Specialty [J]. Journal of Taiyuan University of Technology (Social Sciences Edition), 2015, (01): 71-74.

[2] Huarong. Thoughts and Exploration on the Specialty Construction and Curriculum setup of Electrical Engineering and its Automation [J]. Journal of Shanghai Institute of Applied Technology (Natural Science), 2014 (S1): 34-37.

[3] Zhang Fengge, Ma Shaohua. Discussion on the Reform of training Scheme for Electrical Engineering and its Automation Specialty [J] Journal of Electrical and Electronic Teaching, 2008-30 (1): 16-18.

[4] Gao Xin, Huang Qinzhen. Discussion on the course system of Electrical Engineering and its Automation Specialty [J]. Journal of Southwest University for nationalities (Natural Science Edition), 2003 / 29 (6): 103-106. 